Cochrane Database of Systematic Reviews

\title{
Ionisers for chronic asthma (Review)
}

Blackhall K, Appleton S, Cates CJ

Blackhall K, Appleton S, Cates CJ.

Ionisers for chronic asthma.

Cochrane Database of Systematic Reviews 2012, Issue 9. Art. No.: CD002986.

DOI: 10.1002/14651858.CD002986.pub2.

www.cochranelibrary.com 
TABLE OF CONTENTS

HEADER 1

ABSTRACT

PLAIN LANGUAGE SUMMARY

BACKGROUND

OBJECTIVES

METHODS

RESULTS

DISCUSSION

AUTHORS' CONCLUSIONS

ACKNOWLEDGEMENTS

REFERENCES

CHARACTERISTICS OF STUDIES

DATA AND ANALYSES

Analysis 1.1. Comparison 1 Negative ionised air versus non-ionised air, Outcome 1 FEV1 (Fall \%) after exercise test.

Analysis 1.2. Comparison 1 Negative ionised air versus non-ionised air, Outcome 2 Baseline FEV1(litres) (after inhalation of negative ions prior to exercise testing).

Analysis 1.3. Comparison 1 Negative ionised air versus non-ionised air, Outcome 3 Morning Peak Expiratory Flow (Litres/min). . 16

Analysis 1.4. Comparison 1 Negative ionised air versus non-ionised air, Outcome 4 FEV1 (Litres/min) > 4 weeks. ................... 16

Analysis 1.5. Comparison 1 Negative ionised air versus non-ionised air, Outcome 5 Evening Peak Expiratory Flow (Litres/min). . 16

Analysis 1.6. Comparison 1 Negative ionised air versus non-ionised air, Outcome 6 FEV1 (Fall \%) after histamine challenge. .... 16

Analysis 1.7. Comparison 1 Negative ionised air versus non-ionised air, Outcome 7 Asthma Symptom Score $1 . \quad$............................... 17

Analysis 1.8. Comparison 1 Negative ionised air versus non-ionised air, Outcome 8 Asthma Symptom Score 2. ........................... 17

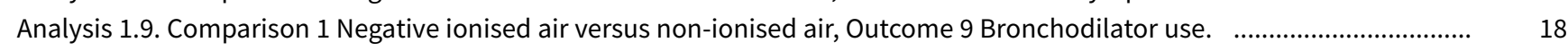

Analysis 1.10. Comparison 1 Negative ionised air versus non-ionised air, Outcome 10 Morning PEFR (First arm change score). .. 18

Analysis 2.1. Comparison 2 Positive ionised air versus non-ionised air, Outcome 1 FEV1 (Fall \%) after exercise test. ................ 19

Analysis 2.2. Comparison 2 Positive ionised air versus non-ionised air, Outcome 2 Baseline FEV1(litres) (after inhalation of 19 positive ions prior to exercise testing).

ADDITIONAL TABLES

WHAT'S NEW

HISTORY

CONTRIBUTIONS OF AUTHORS

DECLARATIONS OF INTEREST

SOURCES OF SUPPORT

INDEX TERMS 
[Intervention Review]

\section{Ionisers for chronic asthma}

Karen Blackhall ${ }^{1}$, Sarah Appleton ${ }^{2}$, Christopher J Cates ${ }^{3}$

${ }^{1}$ Cochrane Injuries Group, London School of Hygiene \& Tropical Medicine, London, UK. 2Deptartment of Medicine, The Queen Elizabeth Hospital, Adelaide, Australia. ${ }^{3}$ Population Health Research Institute, St George's, University of London, London, UK

Contact address: Karen Blackhall, Cochrane Injuries Group, London School of Hygiene \& Tropical Medicine, Keppel Street, London, WC1E7HT, UK. karenblackhall@gmail.com.

Editorial group: Cochrane Airways Group.

Publication status and date: Edited (no change to conclusions), published in Issue 9, 2017.

Citation: Blackhall K, Appleton S, Cates CJ. Ionisers for chronic asthma. Cochrane Database of Systematic Reviews 2012, Issue 9. Art. No.: CD002986. DOI: 10.1002/14651858.CD002986.pub2.

Copyright @ 2017 The Cochrane Collaboration. Published by John Wiley \& Sons, Ltd.

\section{A B S T R A C T}

\section{Background}

Previous reports have shown that ion content in the air may have an effect on respiratory function. Results from studies which test the efficacy of air ionisers to reduce asthma symptoms are often inconclusive and their use as a treatment for asthma remains debatable.

\section{Objectives}

We conducted a systematic review of the available evidence to determine the effectiveness of positive and negative ion generators in people with asthma.

\section{Search methods}

We searched the Cochrane Airways Group Specialised Register, Cochrane Central Register of Controlled Trials (CENTRAL) as well as the alternative medicine database AMED. Searches were current as of June 2012.

\section{Selection criteria}

Randomised controlled trials (parallel or crossover design studies) comparing ionisers with dummy ionisers (being negative or positive ion emitters), in children or adults with chronic asthma.

\section{Data collection and analysis}

Two reviewers independently assessed titles and abstracts of studies and assessed trial quality. Study quality was determined using two methods:The Cochrane approach to allocation concealment and the five point Jadad scale.

\section{Main results}

Six studies were selected for inclusion (106 participants). No results were combined as the studies were all of a crossover design.

EFFECTS OF NEGATIVE ION GENERATORS (five studies)

No study reported a significant difference in lung function between ionised and control air (morning Peak expiratory flow (PEF) - three studies; forced expiratory flow in one second (FEV1) - one study). There were no significant differences in symptoms or beta-2 agonist usage between ionised and control air in three studies.

EFFECTS OF POSITIVE ION GENERATORS (one study)

This study demonstrated that although positively ionised air was associated with a larger fall in FEV1 with exercise, this did not reach statistical significance. Baseline FEV1 was not demonstrated to be significantly different between treatment groups. 


\section{Authors' conclusions}

Based on the evidence currently available from randomised controlled trials, a recommendation cannot be given for the use of room air ionisers to reduce symptoms in patients with chronic asthma.

\section{PLAIN LANGUAGE SUMMARY}

\section{Ionisers for chronic asthma}

Ion generators have been marketed for use in homes to remove dust and smoke particles in order to improve symptoms in people with asthma. Although complex laboratory studies show that ion generators alter airways function, the few studies which have been conducted in the homes of people with asthma, demonstrate no significant benefit in improving lung function or symptoms. 


\section{B A C K G R O U N D}

Asthma is a chronic pulmonary disorder which affects an estimated 3.4 million people in the UK (ONS 1996). A recent National Asthma Campaign survey (Smith 2000) suggests that $42 \%$ of those who have asthma face significant challenges in their daily lives due to their condition. Two thirds of the asthma population are said to be receiving inhaled steroids with many expressing concerns about the long-term effects of their medication (Smith 2000). Although pharmacological interventions continue to improve, the prevalence of asthma remains high (ONS 1996). Such concerns highlight the need for further investigation into the benefits of non-pharmacological treatment in order to compliment pharmacological therapies.

Previous reports have shown that alteration of ions in the air may have an effect on respiratory function (Wehner 1969). As a result, interest has grown in the physiological effects of positive and negative air ions in people with asthma. With the development of ion generators it has become possible to artificially manipulate the ion content in air. Studies (Nogrady 1983; Lipin 1984; Warner 1993) have been carried out to test the efficacy of air ionisers in order to reduce air-borne allergens and smoke particles, with a view to alleviating asthma symptoms. Results of such studies are often inconclusive and the effectiveness of air ionisers as a treatment for asthma remains debatable. This systematic review of the available evidence was conducted in order to summarise the results of all identified randomised controlled trials comparing ionisers to placebo.

\section{O B JECTIVES}

To determine whether air ionisers (positive or negative ion emitters) are effective in relieving symptoms and improving respiratory function in people with chronic asthma.

\section{METHODS}

\section{Criteria for considering studies for this review}

\section{Types of studies}

Randomised controlled trials (parallel or crossover design studies).

\section{Types of participants}

We included studies assessing children and adults with chronic asthma.

\section{Types of interventions}

Inhalation of positively or negatively ionised air, generated by an ioniser in the home or laboratory setting. The comparative group will have inhaled non-ionised air through a dummy ioniser.

\section{Types of outcome measures}

\section{Primary outcomes}

1. Respiratory physiological measures: Peak Expiratory Flow (PEF) and Forced Expiratory Volume in one second (FEV1)

2. Asthma symptom scores

\section{Secondary outcomes}

1. Health-related Quality of Life
2. Exacerbation

3. Provocation tests (e.g. exercise, histamine)

4. Bronchodilator usage

5. Inhaled corticosteroids usage

\section{Search methods for identification of studies}

Trials were identified using the Cochrane Airways Group Specialised Register of trials which is derived from systematic searching of electronic databases including CENTRAL, MEDLINE, EMBASE and CINAHL, and hand-searching of respiratory journals and meeting abstracts. All records in the Specialised Register coded as 'asthma' were searched using the following terms:

(ionis* or ioniz* or "electrostatic precipitator*")

The Cochrane Central Register of Controlled Trials (CENTRAL) was searched using the same terms. Additional searching was carried out on the alternative medicine database AMED (1985 - present) using the search:

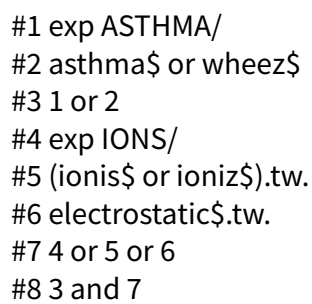

Searches were current as of January 2010.

\section{Data collection and analysis}

\section{Selection of studies}

Two reviewers (KB and SLA) independently assessed titles and abstracts of studies, identified by the database search, and selected studies for inclusion in the review. We also independently assessed the full text of all selected abstracts for suitability for inclusion in the review.

\section{Data extraction and management}

We extracted data independently from the eligible studies. Disagreement was resolved by consensus.

\section{Assessment of risk of bias in included studies}

We independently determined study quality using two methods: (1) The Cochrane approach to allocation concealment using the following grading system:

Grade A: Adequate concealment

Grade B: Uncertain

Grade C: Inadequate concealment

Grade D: allocation concealment not used

(2) The five point Jadad scale (Jadad 1996) according to the following criteria:

(a) Study described as randomised (yes: 1, no: 0)

(b) Method of randomisation described and appropriate (yes: 1, no: $-1)$

(c) Study described as double blind (yes: 1 , no: 0 )

(d) Method of blinding described and appropriate (yes: 1, no: -1) 
(e) There was a description of withdrawals and drop outs (yes: 1 , no: 0$)$

Data were extracted independently by both reviewers and authors of trial reports were contacted for extra or missing information. We resolved any disagreement between reviewers by discussion.

\section{Data synthesis}

Due to the crossover design employed in the studies, we could not reliably pool data from the individual studies in RevMan, and individual study data only is shown in the Forest plots. We extracted first arm data for Nogrady 1983 and analysed this based upon individual patient scores. We reported data for outcomes in the crossover trials in the text of the review.

If parallel group data are available in future versions of this review, we will report pooled analyses as weighted mean differences (WMD) and standardised mean differences (SMD) depending upon the availability of data measured on the same or different metrics. If we can obtain suitable paired data for crossover studies, we will combine this using inverse variance meta-analysis. Where a more positive outcome is favourable, (e.g. PEF) data, we entered this as positive values. In this case the titles of the horizontal axes have been reversed so that effects that favour the treatment under review move to the right. We have graphed continuous outcomes for which lower scores imply improvement (e.g. symptom scores and percentage reduction in FEV1 as a measure of bronchial reactivity) according to standard Cochrane graphical convention such that effects that favour the treatment under review move to the left.

The following data were entered separately on the basis of:

1. charge of ion emission, i.e. positive versus negative ions;

2. duration of exposure to ionised air.

\section{Subgroup analysis and investigation of heterogeneity}

We performed a subgroup analysis on the basis of age group of participants (adults versus children)

\section{RES U L T S}

\section{Description of studies}

\section{Results of the search}

We identified 22 abstracts from the original search , nine of which were not trials. Thirteen full text articles were obtained. Two studies were excluded because they were not randomised (Kirkham 1984; Osterballe 1979) one was excluded because it was neither randomised nor controlled (Jones 1976) and two studies were not suitably controlled (Palti 1966; Zylberberg 1960) One study determined the effect of ionisers on airborne particles but recorded no patient outcomes (Wickman 1989) and one study reported previously published data (Nogrady 1983). A total of six studies were included in this review. An update search conducted in June 2012 did not identify any additional relevant studies.

\section{Included studies}

See Characteristics of included studies for details of individual studies.
We included six studies in this review, all of which utilised a crossover design. The review includes studies conducted between 1983 and 1994 two studies from Israel (Ben-Dov 1983; Lipin 1984) and four studies conducted in Australia (Nogrady 1983), UK (Warner 1993) and Denmark (Daugbjerg 1988; Larsen 1994). Two studies were published in Danish and were translated into English (Daugbjerg 1988; Larsen 1994). The remaining studies were all published in English.

\section{Study design}

All studies were randomised. One was single-blind (Daugbjerg 1988). The remaining studies were double-blind (Ben-Dov 1983; Larsen 1994; Lipin 1984; Nogrady 1983; Warner 1993). No information on methods of randomisation were reported. Larsen 1994 provided details on the method of randomisation upon request.

\section{Participants}

Sixty eight children participated in four studies (Ben-Dov 1983 (n = 17); Lipin $1984(n=12)$; Daugbjerg $1988(n=19)$; Warner 1993 ( $=20)$ ) with an age range of eight months to 20 years. There were 40 adults who participated in two studies (Nogrady $1983(n=20)$; Larsen $1994(n=20)$ ), with a mean age of 36 to 47 years (see Table 1 ).

Diagnosis and severity of asthma were not described in the studies. Ben-Dov 1983 and Lipin 1984 recruited participants known to have had asthma attacks provoked by exercise challenge. Daugbjerg 1988 did not report how a diagnosis of asthma was reached and no baseline data on symptoms were reported. Larsen 1994 recruited participants with an observed variation in peak flow of $>20 \%$ or reversibility of over $15 \%$ in $\mathrm{FEV}_{1}$ after inhalation of $0.2 \mathrm{mg}$ of salbutamol, were treated with $</=1000 \mathrm{mcg}$ inhaled steroids per day and required bronchodilators on a daily basis. Nogrady 1983 made a clinical assessment for asthma at the outset of the study, including PEFR and allergen sensitivity. No other details of clinical examination were reported. Warner 1993 recruited children described as suffering from perennial asthma.

\section{Interventions}

Negatively ionised air was used in four home-based studies (Daugbjerg 1988; Larsen 1994; Nogrady 1983; Warner 1993) and one laboratory based study (Ben-Dov 1983). Positively ionised air was used in one laboratory based study (Lipin 1984).

Nogrady 1983 exposed participants to 150,000 negative ions/ml at night for 10 hours during the 8 week active treatment period. Daugbjerg 1988 exposed participants to 220,000 negative ions per $\mathrm{cm}^{3}$ or placebo for either eight and then four weeks or four and then eight weeks treatment. In Larsen 1994 and Warner 1993 the ion count was not reported. In both studies participants were exposed to an ioniser during the day in the living room and at night in the bedroom for a treatment period of four weeks (Larsen 1994) and six weeks (Warner 1993).

Ben-Dov 1983 exposed participants to negatively charged ions ( 0.5 to $1.0 \times 106$ ions per $\mathrm{cm}^{3}$ for approximately 45 minutes) and conducted identical six minute exercise provocation tests (cycle ergometry) where each challenge was undertaken twice (3 to 24 hours apart) with active and placebo ionisers. Participants were also exposed to 4 to $5 \times 105$ negative ions per $\mathrm{cm}^{3}$ during histamine provocation, with doubling concentrations of histamine 
to a maximum of $10 \mathrm{mg} / \mathrm{ml}$ until a $20 \%$ drop in FEV1 was obtained compared to baseline values. Each challenge was undertaken twice (24 hours apart) with active and placebo ionisers.

Lipin 1984 exposed participants to positively charged ions $(0.5$ to $1.0 \times 106$ ions per $\mathrm{cm} 3$ ) and conducted identical six minute exercise provocation tests (cycle ergometry) where each challenge was undertaken twice (24 hours apart) with and without exposure to the active ioniser.

See Table 2 for a summary of the duration of the included trials.

\section{Outcome measures}

There was variation in the overall outcomes used across the six studies.

The studies conducted under laboratory conditions measured lung function and did not assess symptoms or medication usage (BenDov 1983; Lipin 1984)

Of the remaining studies, assessments were conducted of lung function in three studies (Larsen 1994; Nogrady 1983 and Warner 1993); symptoms were assessed in three studies (Daugbjerg 1988; Larsen 1994 and Warner 1993) and attempts to record medication usage were made in two studies (Daugbjerg 1988; Warner 1993).

One study (Nogrady 1983) reported data with significant differences in baseline measurements (approximately $100 \mathrm{ml}$ difference in PEF) between the two comparison groups possibly due to the gender distribution which is suggestive of unsuccessful randomisation. Results were presented in the form of the two groups, according to whether participants were exposed to the active ioniser or the placebo ioniser first. Data from each group were analysed separately and intra-group comparisons were made between the active and placebo periods. A second publication of the trial contributed no extra data to the review so is listed in 'excluded studies'.

Data from another study (Daugbjerg 1988) does not appear in the table of comparisons as the data were not useable due to the use of non-validated symptom scoring.

\section{Risk of bias in included studies}

Overall, the included papers were of strong study design. All studies were conducted double-blind, except the Daugjberg study (Daugbjerg 1988) which was single blind. The order of the treatments within the crossover were described as randomised but randomisation methods were not stated. However, none of the studies commented on the number of participants excluded from the trials or reported a power calculation to determine sample size. Withdrawals and drop-outs were adequately described.

The sample sizes of each of the six studies were small, ranging from 12 to 20 participants. The total number of participants contributing data from all six studies was 106 .

A wash-out period between treatment arms of two weeks was reported in only one study (Nogrady 1983). Although the duration of exposure in the laboratory studies was short, it is unknown whether a wash-out period of greater than 3 to 24 hours would be required.

Inclusion/exclusion criteria were not formally specified. Inclusion criteria was specified in two studies, with respect to a definition of stable asthma (Larsen 1994), and a concentration of house dust mite allergen Der p1 (Warner 1993). The two laboratory based studies reported a general statement of inclusion of subjects as those being "known to have had asthmatic attacks provoked by physical exertion". Only one study specified exclusion criteria relating to medication use (Larsen 1994).

There was total agreement between two independent assessments of study quality using the Cochrane approach and the Jadad scale. All five studies were graded B according to the Cochrane approach to concealment of allocation as none described the method of concealment of allocation. This is not a major concern if the blinding of participants and assessors was secure. No further details were provided by the authors, about methods of concealment or randomisation, which increased the allocated scores of the included trials. All studies were given a Jadad score of 3.

\section{Effects of interventions \\ EFFECTS OF NEGATIVE ION GENERATORS}

\section{Respiratory physiological measures}

\section{Peak Expiratory Flow}

Morning PEF

Two studies with adult participants (Nogrady 1983; Larsen 1994) did not report significant differences between the exposure periods.

One study conducted in children (Warner 1993) reported no significant difference.

\section{Evening PEF}

No statistically significant differences were reported for evening PEF (Nogrady 1983; Warner 1993; Larsen 1994). No values were presented in the papers.

\section{Forced Expiratory Volume in one second}

\section{Baseline FEV1}

Only one study, which was a laboratory based study in children (Ben-Dov 1983) measured FEV1 after 10 minutes inhalation of control and negatively ionised air, but prior to exercise testing. No significant differences were demonstrated in "Baseline" FEV1 between the treatment groups.

(ii) Percentage fall in FEV1 after exercise provocation Ben-Dov 1983 demonstrated no significant difference in percentage reduction in FEV1 from baseline after exercise provocation in the ionised air exposed group compared to those exposed to control air.

(iii) Percentage fall in FEV1 after histamine provocation Ben-Dov 1983 demonstrated no significant difference in percentage reduction in FEV1 from baseline after histamine provocation in the ionised air exposed group compared to those exposed to control air.

\section{(iv) Absolute FEV1}

Only one study, which was a home based study in adults (Larsen 1994) measured FEV1 after four weeks exposure to control and negatively ionised air. This study determined there was no significant difference in absolute FEV1 (litres) between treatments. 


\section{Asthma symptom scores}

Three studies, one conducted in children (Warner 1993) and two in adults (Nogrady 1983; Larsen 1994) recorded asthma symptoms. The Warner study utilised a different symptom scale while the Nogrady and Larsen studies used the same. These measured five dimensions of symptoms and reported a mean symptom score only, not scores for the individual dimensions including the "Total" dimension. Of these three studies, only the Larsen study reported a "Total" dimension. Thus it was not possible to pool these data in an analysis using a standardised mean difference and the analyses are reported separately according to the use of Asthma Symptom Scale "1" and Asthma Symptom Scale "2".

Using the Asthma Symptom Score "1" (Warner 1993) there were no significant differences between the treatments. After six weeks exposure to both ionised air and control air, in the symptom dimensions of "nighttime wheeze"; "daytime wheeze"; "nighttime cough" and "daytime activity".

Using the Asthma Symptom Score "2" (Larsen 1994) there were no significant differences between the treatments, after four weeks exposure to both ionised and control air, in the symptom dimensions scores of: "total"; "sleep disturbance"; "wheeze"; "activity level"; "coughing" and "sputum production".

Nogrady 1983 also used this scale, however, the authors reported a mean of all five dimensions only. There was no significant difference between exposure periods in the mean symptom score.

\section{Bronchodilator Use}

Three studies recorded participants' asthma medication use (inhaled or oral bronchodilators, corticosteroids, sodium cromoglycate and other medications) (Nogrady 1983; Warner 1993; Larsen 1994). No study reported a significant difference in favour of ionised air versus control.

\section{EFFECTS OF POSITIVE ION GENERATORS}

Only one study measured the effects of positive ions on lung function. This study (Lipin 1984), conducted in children demonstrated that positively ionised air was associated with bronchoconstriction, measured by the maximum fall in FEV1 after exercise from baseline (after 10 minutes exposure to ionised air but before cycling) between treatment groups. The confidence interval of the effect of positive ionisation on FEV1 after exercise includes no difference and also a clinically significant deterioration, but the sample size is too small to draw any firm conclusion. Baseline FEV1 was also demonstrated not to be significantly different between treatment groups.

\section{DISCUSSION}

The impact of weather and the resulting ionic charge of the air has been thought to have an impact on biological systems (Sulman 1984) including the respiratory system (Palti 1966). Studies of the effects of weather on morbidity have been conducted with respect to the Foehn, a dry southerly wind of central Europe (Posse 1975; Gnecchi Ruscone 1985) and although asthma patients often report a worsening of symptoms with weather changes, early studies indicate no relationship (Dantzler 1983; Wagner 1983).

Ion generators have been marketed for use to reverse negative ion depletion and to remove dust and smoke particles by electrostatic precipitation. There is a paucity of data in the literature generated from randomised controlled trials of the effects of ion generators for chronic asthma. Consequently this review has been limited by the small numbers of studies eligible for inclusion in the review and also the inconsistent use of outcome of measures. It is possible that the studies lacked the statistical power to detect changes in outcomes because of the small sample sizes of these studies, ranging from 12 to 20 .

The five studies of the effects of negative ion generators and the one study of the effect of a positive ion generator included in this review have failed generally to demonstrate any benefit of these instruments for the treatment of chronic asthma in children and adults. Relevant outcome measures such as PEF, FEV1 after exercise and histamine provocation, symptom scores and asthma medication showed no significant improvement after extended periods of exposure to charged ions compared to normal/control air. It is important to note however that the Ben-Dov et al study (Ben-Dov 1983), a laboratory based study in children demonstrated that during the active ionisation period, the FEV1 after exercise provocation fell $8 \%$ less than that during the control air period. This reduction in bronchial reactivity was statistically significant using the Student's paired t-test with a $P$ value of less than 0.015 . This reflects the power inherent in a paired t-test, compared to the use of a mean difference. The clinical relevance of this finding generated in a controlled laboratory setting with the concentration of ions at the mouthpiece 100 times the natural concentration in the air is unclear. Furthermore, a statistically significant reduction in bronchial reactivity after histamine challenge did not occur. Interestingly, four of nine participants demonstrated greater histamine sensitivity during inhalation of negative ions compared to control air.

The study by Lipin et al (Lipin 1984) also demonstrated a statistically significant increase in bronchial reactivity after exercise in participants during inhalation of positive ions $(P=0.04)$. In this study, eight of twelve children experienced a greater reduction in FEV1 when the active ioniser was used compared to the placebo ioniser. Two showed no change and two showed a reduction in reactivity. All other outcomes in this review were statistically consistent with those reported by authors of the studies.

Asthma symptoms were not demonstrably improved as a consequence of active ionisation. The two studies, however, which recorded or reported this outcome used two apparently un validated symptom scales; the Nogrady study (Nogrady 1983) which utilised the same scale as the Larsen study (Larsen 1994) reported a mean symptom score of the five dimensions rather than the "Total" dimension score. The frequency of "nighttime cough" recorded in the Warner study (Warner 1993) increased during the ionisation period (exposure to negative ions for six weeks) to a level which approached statistical significance [Wilcoxon signed rank sum test $P=0.055]$. If the use of room air ionisers is to be pursued then this finding requires further investigation.

Asthma medication use was not demonstrated to be significantly reduced during active ionisation compared to when the placebo ioniser was in use. Beta-2 agonist use was an outcome measure in only one of three studies which recorded medication use. The amount of rescue medication used is more likely to reflect a change in condition as compared to other asthma medications. 
One study (Larsen 1994) provoked some interesting correspondence (Jonassen 1996) which suggests the need to carry out initial trials on the efficiency of the ioniser before using it in a trial. The ioniser is an instrumental component in the trial and could potentially influence the trial outcome. Another point about the length of time an ioniser should be turned on in order to 'clean' the air in a room is also worthy of consideration. Any trials implemented to test an improvement of symptoms in asthma patients should consider these points.

In conclusion, individual studies in a laboratory setting suggest that positively ionised air may aggravate exercise induced asthma and negatively ionised air may attenuate exercise induced asthma during exposure to these charged ions at 100 fold the concentration found naturally in the air. No other significant benefit or harm in terms of lung function (baseline and absolute FEV1, PEF), asthma symptoms or medication use were demonstrated and none occurred in the home setting.

\section{AUTHORS' CONCLUSIONS}

\section{Implications for practice}

Based on the evidence currently available from randomised controlled trials, a recommendation cannot be given for the use of room air ionisers in the homes of patients with chronic asthma.

\section{Implications for research}

The strength of evidence from six randomised controlled trials does not suggest that air ionisers are significantly beneficial for patients with chronic asthma. There are no further data to provide additional evidence to support their use and the absence of such data in the medical literature since 1993 suggests a declining interest. The review does suggest, however, that further trials would need to incorporate issues on compliance, efficiency of the ioniser and the environment in which the trial takes place.

\section{A C K N O WLEDGEMENTS}

Thanks to Jane Dennis for her very thorough and accurate translations. Thanks to Toby Lasserson for his support. We gratefully acknowledge the assistance of Vasya Vlassov for helping with translating from Russian. 


\section{REFERE N CES}

\section{References to studies included in this review}

\section{Ben-Dov 1983 \{published data only\}}

Ben-Dov I, Amirav I, Shochina M, Amitai I, Bar-Yishay E, Godfrey S. Effect of negative ionisation of inspired air on the response of asthmatic children to exercise and inhaled histamine. Thorax 1983;38(8):584-8. [MEDLINE: 83302921]

\section{Daugbjerg 1988 \{published data only\}}

Daugbjerg P, Brenoe E, Henriksen E, Ibsen KK. Ion generator and asthmatic bronchitis/bronchial asthma. Evaluation of an ion generator in the treatment of recurrent asthmatic bronchitis and bronchial asthma [longenerator og astmatisk bronchitis/ asthma bronchiale. Evaluering af iongenerator i behandling af recidiverende astmatisk bronchitis og asthma bronchiale hos born]. Ugeskrift for Laeger 1988;150(2):90-4.

\section{Larsen 1994 \{published data only\}}

Larsen KR, Olsen OT, Jarnvig IL, Svendsen UG. Ion generators and bronchial asthma. A double-blind placebo controlled study [longeneratorer og asthma bronchiale. En dobbeltblind placebokontrolleret undersogelse]. Ugeskrift for Laeger 1994;156(41):6025-7.

\section{Lipin 1984 \{published data only\}}

Lipin I, Gur I, Amitai Y, Amirav I, Godfrey S. Effect of positive ionisation of inspired air on the response of asthmatic children to exercise. Thorax 1984;39(8):594-6.

\section{Nogrady 1983 \{published data only\}}

Nogrady S. Air ionisation-its effects in bronchial asthma. Australia and New Zealand Journal of Medicine 1983;13(5):547.

* Nogrady SG, Furnass SB. Ionisers in the management of bronchial asthma. Thorax 1983;38(12):919-22.

Warner 1993 \{published data only\}

* Warner JA, Marchant JL, Warner JO. Double blind trial of ionisers in children with asthma sensitive to the house dust mite. Thorax 1993;48(4):330-3.

\section{References to studies excluded from this review}

Jones 1976 \{published data only\} Jones DP, O'Connor SA, Collins JV, Watson BW. Effect of longterm ionized air treatment on patients with bronchial asthma. Thorax 1976;31(4):428-32.

\section{Kirkham 1984 \{published data only\}}

Kirkham AJ, Hawkins L, Guyatt AR, Lumley K, Horsfield K, Cumming $\mathrm{G}$. The effect of air ionisation on lung function in chronic asthmatics. Clinical Science 1984;67(Suppl 9):62-3.

Mitchell 1980 \{published data only\}

Mitchell EA, Elliott RB. Controlled trial of an electrostatic precipitator in childhood asthma. Lancet 1980;2(8194):559-61.
Nogrady 1983b \{published data only\}

Nogrady S, Furnass B, Stevens D. Air ionisation-its effects in bronchial asthma. Australia and New Zealand Journal of Medicine 1983;13(5):547.

Osterballe 1979 \{published data only\}

Osterballe O, Weeke B, Albrechtsen O. Influence of small atmospheric ions on the airways in patients with bronchial asthma. Allergy 1979;34(3):187-94.

Palti 1966 \{published data only\}

Palti Y, De Nour E, Abrahamov A. The effect of atmospheric ions on the respiratory system of infants. Pediatrics 1966;38(3):405-11.

Ponomarenko 2003 \{published data only\}

* Ponomarenko GN, Ponomareva EV, Sereda VP. Biocontrolled aeroionotherapy - a new method of treatment in patients with bronchial asthma [Bioupravliaemaia aeroionoterapiia - novyi metod lecheniia bol'nykh bronkhial'noi astmoi]. Vopr Kurortol Fizioter Lech Fiz Kult 2003;5:17-9.

Wickman 1989 \{published data only\}

Wickman M, Sandvik L, Aas K. Ion generators are not a complement to asthma treatment in children [Jongeneratorer inget komplement $\mathrm{i}$ astmabehandlingen hos barn]. Lakartidningen 1989;86(20):1889-90.

Zylberberg 1960 \{published data only\} Zylberberg B, Loveless MH. Preliminary experiments with ionized air in asthma. Journal of Allergy 1960;31(4):370-4.

\section{References to studies awaiting assessment}

Yunus 2012 \{published data only\}

Yunus F, Sutoyo DK. The effect of air filter with balanced anioncation usage on airway inflammation, asthma control, and lung function test of allergic asthma patients. Respirology 2012;17:6.

\section{Additional references}

\section{Dantzler 1983}

Dantzler BS, Martin BG, Nelson HS. The effect of positive and negative air ions on bronchial asthma. Annals of Allergy 1983;51:362-6.

\section{Gnecchi Ruscone 1985}

Gnecchi Ruscone T, Crosignani P, Micheletti T, Sala L, Santomauro D. Meteorological influences on myocardial infarction in the metropolitan area of Milan. International Journal of Cardiology 1985;9:75-80.

\section{Jadad 1996}

Jadad AR, Moore RA, Carroll D, Jenkinson C, Reynolds DJM, Gavaghan GJ, et al. Assessing the quality of reports of randomised trials: is blinding necessary?. Controlled Clinical Trials 1996;17:1-12. 


\section{Jonassen 1996}

Jonassen $\mathrm{N}$. Ion generators and bronchial asthma [longeneratorer og asthma bronchiale]. Ugeskrift for Laeger 1996;158(29):4203-5.

\section{ONS 1996}

Office for National Statistics, Government Statistical Service. Key health statistics from general practice. Studies on medical and population subjects; No. 60. 1996.

\section{Posse 1975}

Posse P. Effect of weather on morbidity dynamics in a large city. An investigation on the population of Munich. Munchener Medizinische Wochenschrift 1975;117:425-30.

\section{Smith 2000}

Smith NM [on behalf of the National Asthma Campaign]. The 'needs of people with asthma' survey and initial presentation of the data. Asthma Journal 2000;5:133-7.

\section{CHARACTERISTICS OF STUDIES}

Characteristics of included studies [ordered by study ID]

\section{Sulman 1984}

Sulman FG. The impact of weather on human health. Reviews on Environmental Health 1984;4:83-119.

\section{Wagner 1983}

Wagner CJ, Danziger RE, Nelson HS. Relation between positive small air ions, weather fronts and pulmonary function in patients with bronchial asthma. Annals of Allergy 1983;51:430-5.

\section{Wehner 1969}

Wehner AP. Electro-aerosols, air ions and physical medicine. American Journal of Physical Medicine 1969;48(3):119-49.

* Indicates the major publication for the study

\section{Ben-Dov 1983}

\begin{tabular}{|c|c|}
\hline Methods & $\begin{array}{l}\text { Crossover study } \\
\text { Randomisation method: unclear } \\
\text { Blinding: Double-Blind } \\
\text { Excluded: not described } \\
\text { Withdrawals: None stated } \\
\text { Baseline characteristics: comparable } \\
\text { Power calculation: not given } \\
\text { Jadad Score: } 3\end{array}$ \\
\hline \multirow[t]{2}{*}{ Participants } & $\begin{array}{l}\text { Total }=17 \text { children with asthma } \\
\text { (17 completing trial) } \\
\text { Gender-11M:6F. Age range } 10-20 \text { years, mean age } 12.5 \text { years } \\
\text { All patients had exercise-induced asthma } \\
\text { Inclusion/exclusion criteria-not stated } \\
11 \text { exercised challenged } \\
10 \text { histamine challenged } \\
\text { (4 participated in both) }\end{array}$ \\
\hline & No details of severity reported \\
\hline Interventions & $\begin{array}{l}\text { Laboratory-based study: } \\
\text { Negatively ionised air ( } 4 \times 10 / 5-10 \times 10 / 5 \text { ions / } \mathrm{cm} 3) \text { versus } \\
\text { Control room or non-ionised air. } \\
10 \text { minutes pre-challenge (exercise and histamine) exposure, } 6 \text { minutes exercise test 3-24 hours apart. } \\
3 \text { minutes post-histamine challenge measurement. } \\
\text { Histamine provocative dose = PD20 }\end{array}$ \\
\hline Outcomes & FEV1 measurement pre-challenge, during challenge and post-challenge \\
\hline \multicolumn{2}{|l|}{ Notes } \\
\hline \multicolumn{2}{|l|}{ Risk of bias } \\
\hline Bias & Authors' judgement Support for judgement \\
\hline
\end{tabular}


Ben-Dov 1983 (Continued)

Allocation concealment Unclear risk
(selection bias)

\section{Daugbjerg 1988}

$\begin{array}{ll}\text { Methods } & \text { Crossover study } \\ & \text { Randomisation method: unclear } \\ & \text { Blinding: single blind } \\ & \text { Excluded: not described } \\ & \text { Withdrawals: } 3 \\ & \text { No baseline statistics given } \\ & \text { Power calculation: not given } \\ \text { Jadad score: } 3\end{array}$

\begin{tabular}{|c|c|}
\hline Participants & $\begin{array}{l}\text { Total = } 19 \text { children ( } 16 \text { completing trial) } \\
\text { Gender: } 12 \mathrm{~m}: 7 \mathrm{~F} \\
\text { (9m:7F completing) } \\
\text { Average age } 63 \text { months } \\
\text { No baseline measurements taken } \\
\text { All patients had asthma or 'Wheezy Bronchitis' } \\
\text { Inclusion/exclusion criteria-not stated } \\
\text { No details of severity reported. }\end{array}$ \\
\hline Interventions & $\begin{array}{l}\text { Home-based study: negatively ionised air versus control/non-ionised air } \\
3 \times 4 \text {-week periods }\end{array}$ \\
\hline Outcomes & $\begin{array}{l}\text { In house developed four point symptom score; medication usage; parent reported school ab- } \\
\text { sence/days of sickness }\end{array}$ \\
\hline Notes & Results not usable \\
\hline \multicolumn{2}{|l|}{ Risk of bias } \\
\hline Bias & Authors' judgement Support for judgement \\
\hline $\begin{array}{l}\text { Allocation concealment } \\
\text { (selection bias) }\end{array}$ & Information not available \\
\hline
\end{tabular}

Larsen 1994

$\begin{array}{ll}\text { Methods } & \text { Crossover study } \\ \text { Randomisation method: Third party drew 'active' or 'placebo' labels out of an envelope (personal } \\ \text { communication from trialist). } \\ \text { Blinding: Double-blind } \\ \text { Excluded: not stated } \\ \text { Withdrawals: } 1 \\ \text { Baseline characteristics: comparable } \\ \text { Power calculation: not given } \\ \text { Jadad score: } 5\end{array}$

$\begin{array}{ll}\text { Participants } & \text { Total }=20 \text { adults (19 completing trial) } \\ & \text { Gender: } 9 \mathrm{M}: 10 \mathrm{~F} \text { (one dropout), Age range 18-60 years, mean age } 47 \\ & \text { All patients had asthma }\end{array}$


Larsen 1994 (Continued)

Inclusion criteria-stable asthma defined by oral steroid use

Variation in PEF of $>20 \%$ or $>15 \%$ FEV1 reversibility after $0.2 \mathrm{mg}$ salbutamol delivered by spacer

Inhaled steroid use $<1000 \mathrm{mcg} /$ day ipratropium bromide/sodium cromoglycate

\begin{tabular}{|c|c|c|}
\hline Interventions & \multicolumn{2}{|c|}{$\begin{array}{l}\text { Home-based } \\
\text { lonised air versus control/ } \\
\text { non-ionised air } 24 \text { hours per day, Positive or negative not stated } \\
\text { lonised air for } 4 \text { weeks then control air for } 4 \text { weeks }\end{array}$} \\
\hline Outcomes & \multicolumn{2}{|c|}{ Morning/evening PEF. FEV1, FVC, VC, Symptom scores } \\
\hline Notes & \multicolumn{2}{|c|}{$\begin{array}{l}\text { Jadad score: } 5 \\
\text { Higher scoring due to extra information provided by author through personal communication }\end{array}$} \\
\hline \multicolumn{3}{|l|}{ Risk of bias } \\
\hline Bias & Authors' judgement & Support for judgement \\
\hline $\begin{array}{l}\text { Allocation concealment } \\
\text { (selection bias) }\end{array}$ & Low risk & Sealed envelope; investigators unaware as to treatment group assignment \\
\hline
\end{tabular}

\section{Lipin 1984}

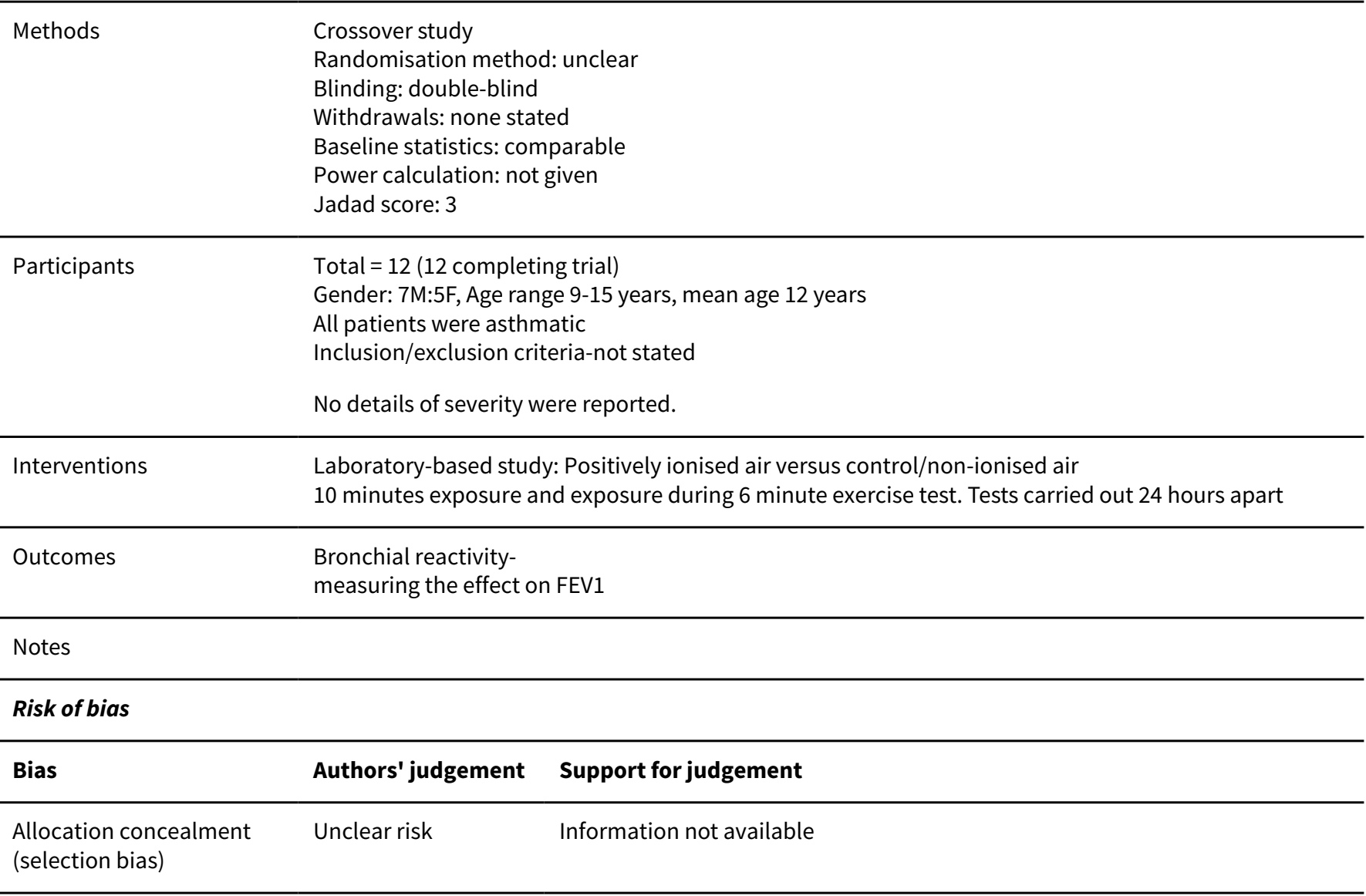


Nogrady 1983

\begin{tabular}{|c|c|c|}
\hline Methods & \multicolumn{2}{|c|}{$\begin{array}{l}\text { Crossover study } \\
\text { Randomisation method: unclear } \\
\text { Blinding: double-blind } \\
\text { Excluded: not stated } \\
\text { Withdrawals: } 1 \\
\text { Power calculation: not given } \\
\text { Jadad score: } 3\end{array}$} \\
\hline Participants & \multicolumn{2}{|c|}{$\begin{array}{l}\text { Original version of study had a total no. }=20 \text { adult } \\
\text { (19 completing trial). } \\
\text { Gender: } 10 \mathrm{M}: 9 \mathrm{~F} \text { Mean age } 36 \text { years } \\
\text { Original study group of } 20 \text { separated into groups (a) and (b) because of gender distribution between } \\
\text { groups and baseline lung function higher probably due to gender distribution } \\
\text { All patients had asthma } \\
\text { Inclusion/exclusion criteria-not stated } \\
\text { Group (a) consists of } 10 \text { subjects: } 8 \text { males and } 2 \text { females, which started study on the active ioniser and } \\
\text { whose mean (SD) baseline characteristics were: } \\
\text { am PEF: } 399(132) \\
\text { pm PEF: } 442(103) \\
\text { symptom score: } 1.8(1.85) \\
\text { medication: } 5.9(2.9) \\
\text { See Nogrady (b) }\end{array}$} \\
\hline Interventions & \multicolumn{2}{|c|}{$\begin{array}{l}\text { Home-based } \\
\text { Negatively ionised air or control/ } \\
\text { non-ionised air. } 2 \times 8 \text { week treatment arms with } 4 \text { weeks washout. Total length of trial } 6 \text { months }\end{array}$} \\
\hline Outcomes & \multicolumn{2}{|c|}{ Morning PEF measurement; Sympton scores } \\
\hline \multicolumn{3}{|l|}{ Notes } \\
\hline \multicolumn{3}{|l|}{ Risk of bias } \\
\hline Bias & Authors' judgement & Support for judgement \\
\hline $\begin{array}{l}\text { Allocation concealment } \\
\text { (selection bias) }\end{array}$ & Unclear risk & Information not available \\
\hline
\end{tabular}

Warner 1993

\begin{tabular}{ll}
\hline Methods & Crossover study \\
& Randomisation method: unclear \\
& Blinding: double-blind \\
Excluded: not stated & Withdrawals: not described \\
Baseline characteristics: comparable & Power calculation: not given \\
Jadad score: 3 & \\
Total = 20 (20 completing the trial) & No gender ration given. \\
Age range $3-11$ years, median age 9 years \\
All patients had asthma \\
Inclusion criteria-Der p1 concentration in the living room and child's bedroom $>2 \mathrm{mg} / \mathrm{m} 3$ air \\
No details of severity reported.
\end{tabular}


Warner 1993 (Continued)
Interventions
Home-based
Negatively lonised air versus non-ionised air/ control air. 6 weeks ionised, 6 weeks non-ionised/con- trol. Air sampling performed at beginning, middle and end of each period

Morning/evening PEF, nightitme wheeze, daytime wheeze, nighttime cough, daytime cough, daytime activity, medication

\section{Notes}

\section{Risk of bias}

\begin{tabular}{lll}
\hline Bias & Authors' judgement & Support for judgement \\
\hline $\begin{array}{l}\text { Allocation concealment } \\
\text { (selection bias) }\end{array}$ & Unclear risk & Information not available \\
\hline
\end{tabular}

\section{Characteristics of excluded studies [ordered by study ID]}

\begin{tabular}{ll}
\hline Study & Reason for exclusion \\
\hline Jones 1976 & $\begin{array}{l}\text { Not randomised } \\
\text { No control group }\end{array}$ \\
\hline Kirkham 1984 & Not randomised \\
\hline Mitchell 1980 & $\begin{array}{l}\text { No placebo treatment } \\
\text { Not blinded }\end{array}$ \\
\hline Nogrady $1983 \mathrm{~b}$ & Secondary report of included study [Nogrady(a) and Nogrady(b)] No extra data extracted \\
\hline Osterballe 1979 & Not randomised \\
\hline Palti 1966 & $\begin{array}{l}\text { Groups not comparable. One group of 13 suffering from asthmatic bronchitis. One group of } 6 \text { with } \\
\text { no respiratory problems. }\end{array}$ \\
\hline Ponomarenko 2003 & \begin{tabular}{l} 
Study inadequately described to determine whether it was randomised or not. \\
\hline Wickman 1989
\end{tabular} \\
\hline $\begin{array}{l}\text { Randomised control trial measuring the ionisers effect on the reduction of airborne particles. Cor- } \\
\text { respondence with author revealed no patient data as none was originally recorded. }\end{array}$
\end{tabular}

\section{DATA AND ANALYSES}


Comparison 1. Negative ionised air versus non-ionised air

\begin{tabular}{|c|c|c|c|c|}
\hline Outcome or subgroup title & $\begin{array}{l}\text { No. of } \\
\text { studies }\end{array}$ & $\begin{array}{l}\text { No. of } \\
\text { partici- } \\
\text { pants }\end{array}$ & Statistical method & Effect size \\
\hline 1 FEV1 (Fall \%) after exercise test & 1 & & Mean Difference (IV, Fixed, 95\% CI) & Totals not selected \\
\hline 1.1 Adults & 0 & & Mean Difference (IV, Fixed, 95\% CI) & $0.0[0.0,0.0]$ \\
\hline 1.2 Children & 1 & & Mean Difference (IV, Fixed, 95\% CI) & $0.0[0.0,0.0]$ \\
\hline $\begin{array}{l}2 \text { Baseline FEV1(litres) (after inhala- } \\
\text { tion of negative ions prior to exer- } \\
\text { cise testing) }\end{array}$ & 1 & & Mean Difference (IV, Fixed, 95\% CI) & Totals not selected \\
\hline 2.1 Adults & 0 & & Mean Difference (IV, Fixed, 95\% CI) & $0.0[0.0,0.0]$ \\
\hline 2.2 Children & 1 & & Mean Difference (IV, Fixed, 95\% CI) & $0.0[0.0,0.0]$ \\
\hline $\begin{array}{l}3 \text { Morning Peak Expiratory Flow } \\
\text { (Litres/min) }\end{array}$ & 3 & & Mean Difference (IV, Fixed, 95\% CI) & Totals not selected \\
\hline 3.1 Adults & 2 & & Mean Difference (IV, Fixed, 95\% CI) & $0.0[0.0,0.0]$ \\
\hline 3.2 Children & 1 & & Mean Difference (IV, Fixed, 95\% CI) & $0.0[0.0,0.0]$ \\
\hline 4 FEV1 (Litres/min) $>4$ weeks & 1 & & Mean Difference (IV, Fixed, 95\% CI) & Totals not selected \\
\hline 4.1 Adults & 1 & & Mean Difference (IV, Fixed, 95\% CI) & $0.0[0.0,0.0]$ \\
\hline 4.2 Children & 0 & & Mean Difference (IV, Fixed, 95\% CI) & $0.0[0.0,0.0]$ \\
\hline $\begin{array}{l}5 \text { Evening Peak Expiratory Flow } \\
\text { (Litres/min) }\end{array}$ & 3 & & Mean Difference (IV, Fixed, 95\% CI) & Totals not selected \\
\hline 5.1 Adults & 2 & & Mean Difference (IV, Fixed, 95\% CI) & $0.0[0.0,0.0]$ \\
\hline 5.2 Children & 1 & & Mean Difference (IV, Fixed, 95\% CI) & $0.0[0.0,0.0]$ \\
\hline $\begin{array}{l}6 \text { FEV1 (Fall \%) after histamine chal- } \\
\text { lenge }\end{array}$ & 1 & & Mean Difference (IV, Fixed, 95\% CI) & Totals not selected \\
\hline 6.1 Adults & 0 & & Mean Difference (IV, Fixed, 95\% CI) & $0.0[0.0,0.0]$ \\
\hline 6.2 Children & 1 & & Mean Difference (IV, Fixed, 95\% CI) & $0.0[0.0,0.0]$ \\
\hline 7 Asthma Symptom Score 1 & 1 & & Mean Difference (IV, Fixed, 95\% CI) & Totals not selected \\
\hline 7.1 nighttime wheeze & 1 & & Mean Difference (IV, Fixed, 95\% CI) & $0.0[0.0,0.0]$ \\
\hline 7.2 daytime wheeze & 1 & & Mean Difference (IV, Fixed, 95\% CI) & $0.0[0.0,0.0]$ \\
\hline 7.3 nighttime cough & 1 & & Mean Difference (IV, Fixed, 95\% CI) & $0.0[0.0,0.0]$ \\
\hline 7.4 daytime activity & 1 & & Mean Difference (IV, Fixed, 95\% CI) & $0.0[0.0,0.0]$ \\
\hline 8 Asthma Symptom Score 2 & 2 & & Mean Difference (IV, Fixed, 95\% CI) & Totals not selected \\
\hline
\end{tabular}




\begin{tabular}{|c|c|c|c|c|}
\hline Outcome or subgroup title & $\begin{array}{l}\text { No. of } \\
\text { studies }\end{array}$ & $\begin{array}{l}\text { No. of } \\
\text { partici- } \\
\text { pants }\end{array}$ & Statistical method & Effect size \\
\hline 8.1 sleep disturbance & 1 & & Mean Difference (IV, Fixed, 95\% CI) & $0.0[0.0,0.0]$ \\
\hline 8.2 wheeze & 1 & & Mean Difference (IV, Fixed, 95\% CI) & $0.0[0.0,0.0]$ \\
\hline 8.3 activity level & 1 & & Mean Difference (IV, Fixed, 95\% CI) & $0.0[0.0,0.0]$ \\
\hline 8.4 coughing & 1 & & Mean Difference (IV, Fixed, 95\% CI) & $0.0[0.0,0.0]$ \\
\hline 8.5 sputum production & 1 & & Mean Difference (IV, Fixed, 95\% CI) & $0.0[0.0,0.0]$ \\
\hline 8.6 TOTAL & 1 & & Mean Difference (IV, Fixed, 95\% CI) & $0.0[0.0,0.0]$ \\
\hline $\begin{array}{l}8.7 \text { mean score of all five dimen- } \\
\text { sions }\end{array}$ & 1 & & Mean Difference (IV, Fixed, 95\% CI) & $0.0[0.0,0.0]$ \\
\hline 9 Bronchodilator use & 3 & & $\begin{array}{l}\text { Std. Mean Difference (IV, Fixed, 95\% } \\
\mathrm{Cl} \text { ) }\end{array}$ & Totals not selected \\
\hline 9.1 Adults & 2 & & $\begin{array}{l}\text { Std. Mean Difference (IV, Fixed, 95\% } \\
\text { CI) }\end{array}$ & $0.0[0.0,0.0]$ \\
\hline 9.2 Children & 1 & & $\begin{array}{l}\text { Std. Mean Difference (IV, Fixed, 95\% } \\
\mathrm{CI} \text { ) }\end{array}$ & $0.0[0.0,0.0]$ \\
\hline $\begin{array}{l}10 \text { Morning PEFR (First arm change } \\
\text { score) }\end{array}$ & 1 & & Mean Difference (IV, Fixed, 95\% CI) & Totals not selected \\
\hline
\end{tabular}

Analysis 1.1. Comparison 1 Negative ionised air versus non-ionised air, Outcome 1 FEV1 (Fall \%) after exercise test.

\begin{tabular}{|c|c|c|c|c|c|c|c|}
\hline \multirow[t]{2}{*}{ Study or subgroup } & \multicolumn{2}{|c|}{ lonised air } & \multicolumn{2}{|c|}{ Non-ionised air } & \multirow{2}{*}{\multicolumn{2}{|c|}{$\begin{array}{c}\text { Mean Difference } \\
\text { Fixed, } 95 \% \mathrm{Cl}\end{array}$}} & \multirow{2}{*}{$\begin{array}{c}\text { Mean Difference } \\
\text { Fixed, } 95 \% \mathrm{Cl}\end{array}$} \\
\hline & $\mathbf{N}$ & Mean(SD) & $\mathbf{N}$ & Mean(SD) & & & \\
\hline \multicolumn{8}{|l|}{ 1.1.1 Adults } \\
\hline \multicolumn{8}{|l|}{ 1.1.2 Children } \\
\hline Ben-Dov 1983 & 11 & $21(9.9)$ & 11 & $29(16.6)$ & 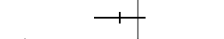 & & $-8[-19.42,3.42]$ \\
\hline
\end{tabular}

Analysis 1.2. Comparison 1 Negative ionised air versus non-ionised air, Outcome 2 Baseline FEV1(litres) (after inhalation of negative ions prior to exercise testing).

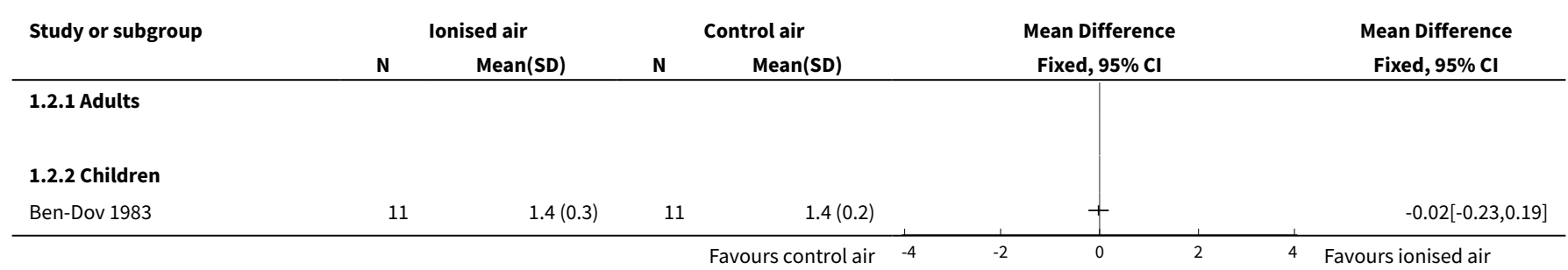


Analysis 1.3. Comparison 1 Negative ionised air versus nonionised air, Outcome 3 Morning Peak Expiratory Flow (Litres/min).

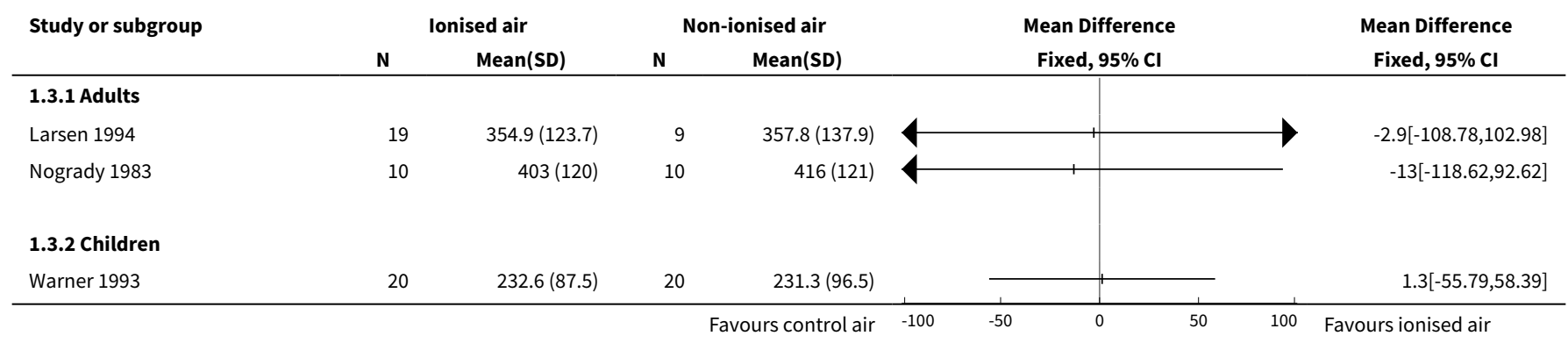

Analysis 1.4. Comparison 1 Negative ionised air versus non-ionised air, Outcome 4 FEV1 (Litres/min) $>4$ weeks.

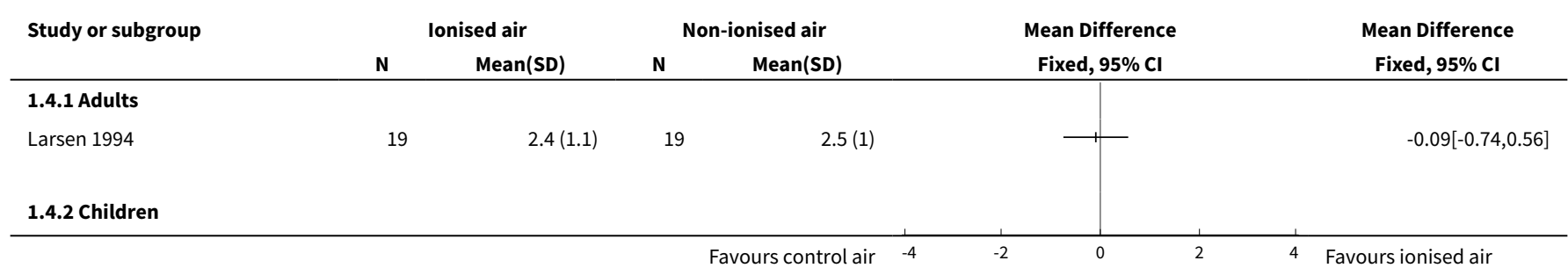

Analysis 1.5. Comparison 1 Negative ionised air versus nonionised air, Outcome 5 Evening Peak Expiratory Flow (Litres/min).

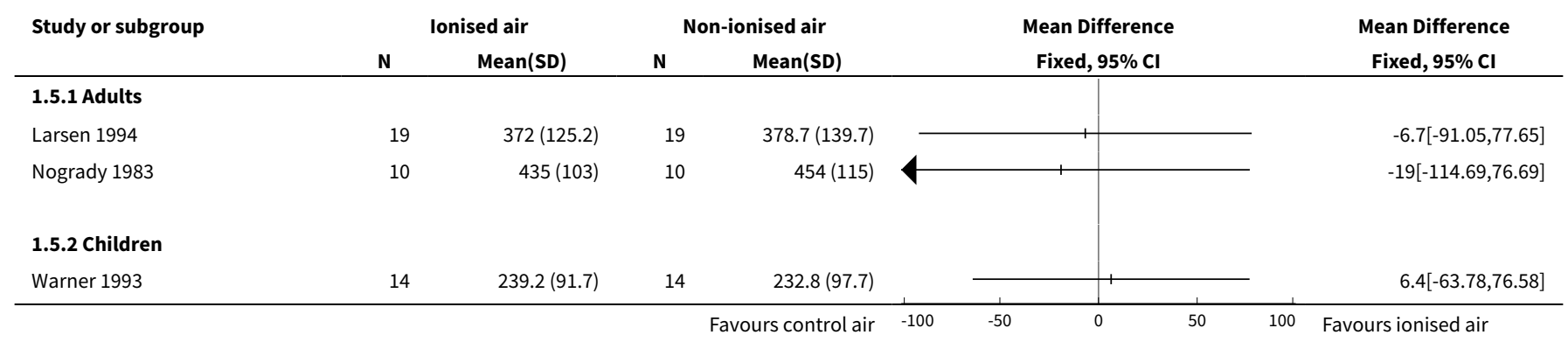

Analysis 1.6. Comparison 1 Negative ionised air versus nonionised air, Outcome 6 FEV1 (Fall \%) after histamine challenge.

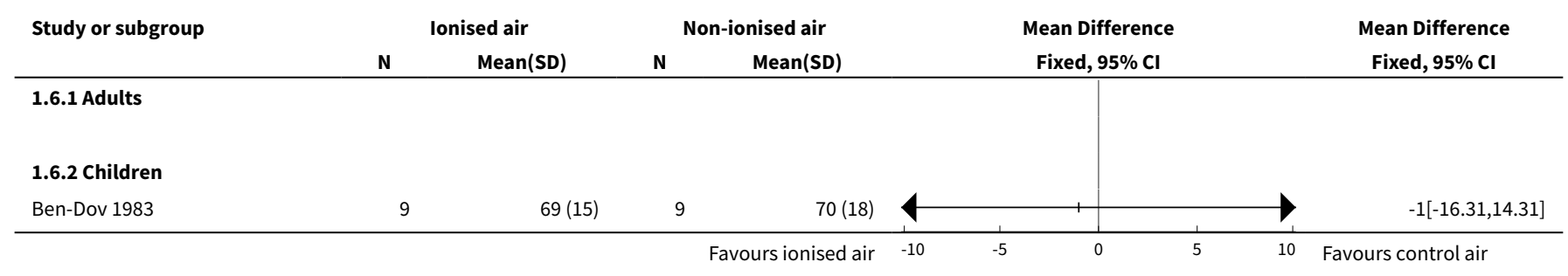


Analysis 1.7. Comparison 1 Negative ionised air versus non-ionised air, Outcome 7 Asthma Symptom Score 1.

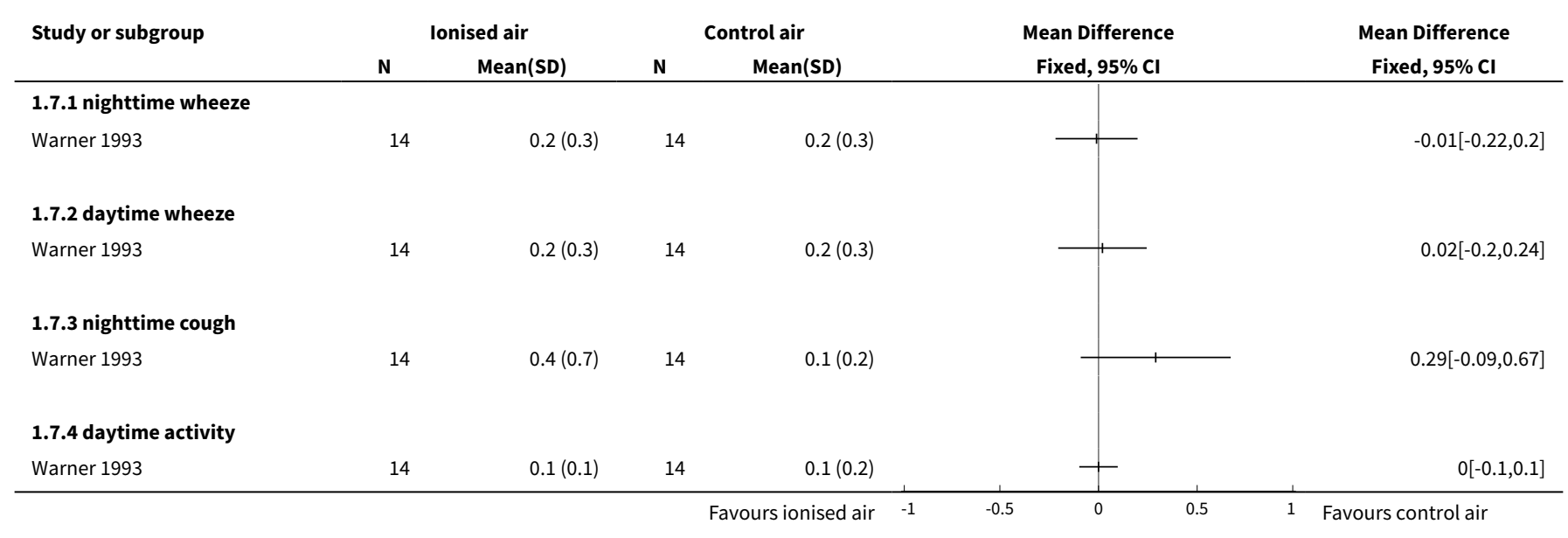

Analysis 1.8. Comparison 1 Negative ionised air versus non-ionised air, Outcome 8 Asthma Symptom Score 2.

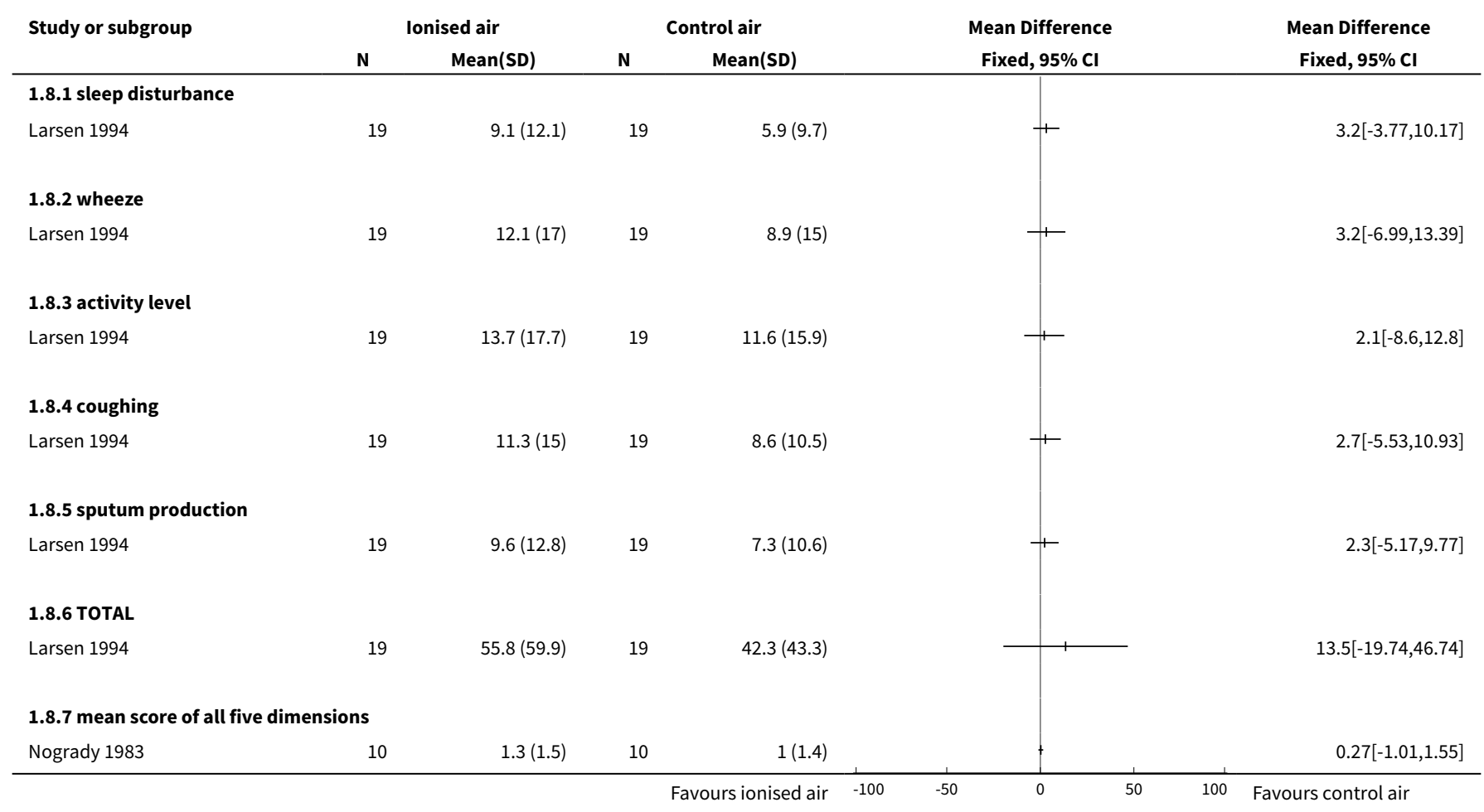


Analysis 1.9. Comparison 1 Negative ionised air versus non-ionised air, Outcome 9 Bronchodilator use.

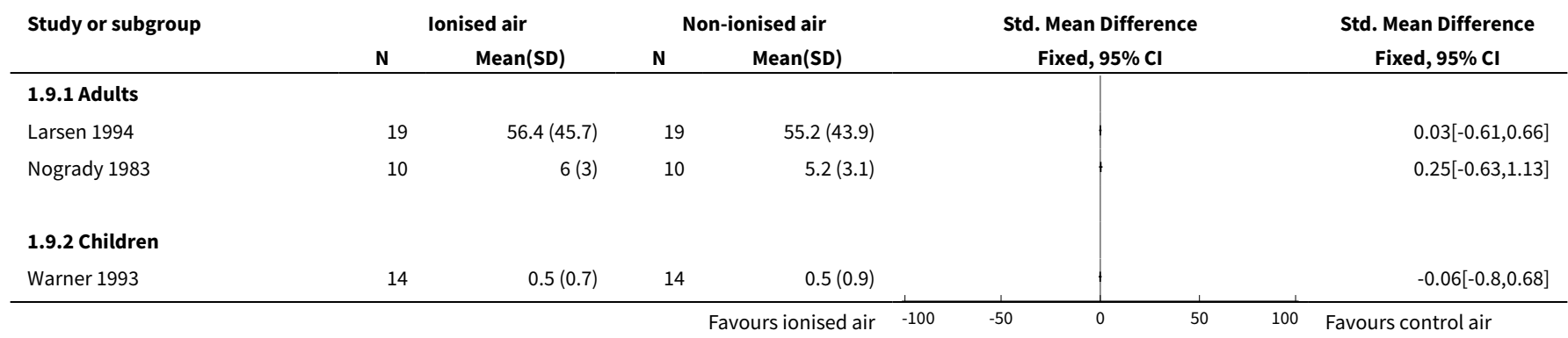

Analysis 1.10. Comparison 1 Negative ionised air versus nonionised air, Outcome 10 Morning PEFR (First arm change score).

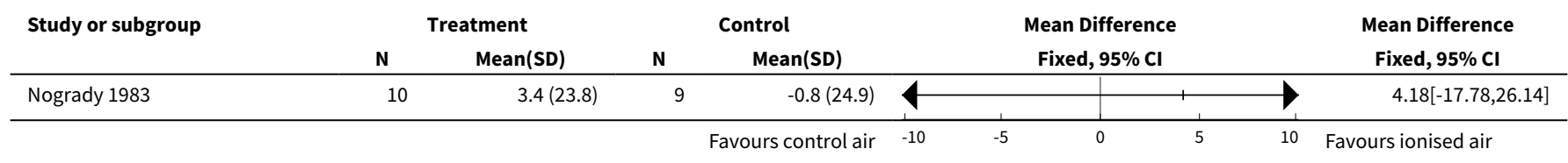

\section{Comparison 2. Positive ionised air versus non-ionised air}

\begin{tabular}{|c|c|c|c|c|}
\hline Outcome or subgroup title & $\begin{array}{l}\text { No. of } \\
\text { studies }\end{array}$ & $\begin{array}{l}\text { No. of } \\
\text { partici- } \\
\text { pants }\end{array}$ & Statistical method & Effect size \\
\hline 1 FEV1 (Fall \%) after exercise test & 1 & & $\begin{array}{l}\text { Mean Difference (IV, Fixed, 95\% } \\
\mathrm{CI})\end{array}$ & Totals not selected \\
\hline 1.1 Adults & 0 & & $\begin{array}{l}\text { Mean Difference (IV, Fixed, 95\% } \\
\mathrm{Cl} \text { ) }\end{array}$ & $0.0[0.0,0.0]$ \\
\hline 1.2 Children & 1 & & $\begin{array}{l}\text { Mean Difference (IV, Fixed, 95\% } \\
\mathrm{Cl} \text { ) }\end{array}$ & $0.0[0.0,0.0]$ \\
\hline $\begin{array}{l}2 \text { Baseline FEV1(litres) (after inhalation of } \\
\text { positive ions prior to exercise testing) }\end{array}$ & 1 & & $\begin{array}{l}\text { Mean Difference (IV, Fixed, 95\% } \\
\mathrm{Cl} \text { ) }\end{array}$ & Totals not selected \\
\hline 2.1 Adults & 0 & & $\begin{array}{l}\text { Mean Difference (IV, Fixed, 95\% } \\
\mathrm{Cl} \text { ) }\end{array}$ & $0.0[0.0,0.0]$ \\
\hline 2.2 Children & 1 & & $\begin{array}{l}\text { Mean Difference (IV, Fixed, 95\% } \\
\mathrm{CI} \text { ) }\end{array}$ & $0.0[0.0,0.0]$ \\
\hline
\end{tabular}


Analysis 2.1. Comparison 2 Positive ionised air versus non-ionised air, Outcome 1 FEV1 (Fall \%) after exercise test.

\begin{tabular}{llcccc} 
Study or subgroup & & lonised air & & Non-ionised air & Mean Difference \\
& N & Mean(SD) & N & Mean(SD) & Fixed, 95\% Cl \\
\hline
\end{tabular}

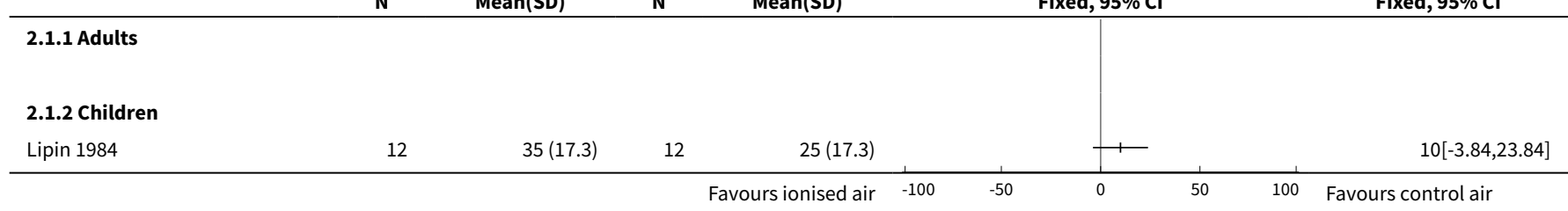

Analysis 2.2. Comparison 2 Positive ionised air versus non-ionised air, Outcome 2 Baseline FEV1(litres) (after inhalation of positive ions prior to exercise testing).

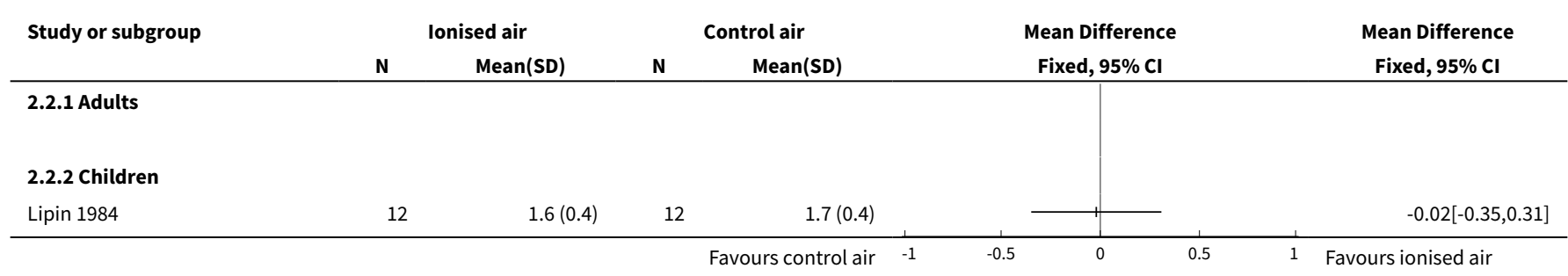

\section{ADDITIONAL TABLES}

Table 1. Age groups of participants

\begin{tabular}{llll}
\hline Study & $\begin{array}{l}\text { No of pa- } \\
\text { tients }\end{array}$ & Average age & Age range \\
\hline Ben-Dov 1983 & 17 & 12.5 years & $10-20$ years \\
\hline Daugbjerg 1988 & 19 & 63 months & $8-47$ months \\
\hline Larsen 1994 & 19 & 47 years & $18-60$ years \\
\hline Lipin 1984 & 12 & 12 years & $9-15$ years \\
\hline Nogrady 1983 & 19 & 36 years & No range given \\
\hline Warner 1993 & 20 & 9 years & $9-14$ \\
\hline
\end{tabular}

Table 2. Duration of trial

\begin{tabular}{llll}
\hline Study & Intervention & $\begin{array}{l}\text { Between interven- } \\
\text { tion }\end{array}$ & Total duration \\
\hline Ben-Dov 1983 & 10 minute exercise/histamine test & 24 hours & Unclear \\
\hline Daugbjerg 1988 & 1 week treatment/placebo & 1 week & 4 weeks \\
\hline
\end{tabular}


Table 2. Duration of trial (Continued)

\begin{tabular}{llll} 
Larsen 1994 & 4 weeks treatment/placebo & None & 8 weeks \\
\hline Lipin 1984 & 6 minute exercise test & 24 hours & Unclear \\
\hline Nogrady 1983 & 8 weeks treatment/placebo & 4 weeks (washout) & 6 months \\
\hline Warner 1993 & 6 weeks & None & 12 weeks \\
\hline
\end{tabular}

WHAT'S NEW

\begin{tabular}{lll}
\hline Date & Event & Description \\
\hline 4 September 2017 & Amended & $\begin{array}{l}\text { New literature search run (7 February 2017) to assess the need to } \\
\text { update this review. One potentially eligible study identified and } \\
\text { added to Studies awaiting classification. }\end{array}$ \\
\hline
\end{tabular}

\section{H I S T O R Y}

Protocol first published: Issue 4, 2000

Review first published: Issue 3, 2003

\begin{tabular}{|c|c|c|}
\hline Date & Event & Description \\
\hline \multirow[t]{2}{*}{22 June 2012} & New search has been performed & New literature search run, no new eligible studies identified. \\
\hline & & $\begin{array}{l}\text { There have been no new studies published on this topic in the } \\
\text { past } 18 \text { years and therefore we have moved this topic to a longer } \\
\text { search cycle. We plan to update the literature search in Feb } \\
2017 \text {. If you are aware of the publication of any potentially eligi- } \\
\text { ble trials in the interim period, please let us know using the "sub- } \\
\text { mit comments" button for this review on The Cochrane Library. }\end{array}$ \\
\hline 22 June 2012 & $\begin{array}{l}\text { New citation required but conclusions } \\
\text { have not changed }\end{array}$ & New literature search run. \\
\hline 19 January 2010 & New search has been performed & Literature search re-run; no new studies. \\
\hline 1 August 2008 & Amended & Converted to new review format. \\
\hline 1 February 2003 & $\begin{array}{l}\text { New citation required and conclusions } \\
\text { have changed }\end{array}$ & Substantive amendment \\
\hline
\end{tabular}

\section{CONTRIBUTIONS OF AUTHORS}

$\mathrm{KB}$ and SLA developed the protocol with suggested changes from CJC $K B$ carried out searches and KB and SLA reviewed abstracts for inclusion $K B$ and SLA extracted data with advice on data entry from CJC

SLA conducted the meta-analysis and reported results

$\mathrm{KB}$ wrote the abstract. SLA and KB developed the discussion and conclusion section with CJC. 


\section{DECLARATIONS OF INTEREST}

None known.

\section{SOURCES OF SUPPORT}

\section{Internal sources}

- None, UK.

\section{External sources}

- None, UK.

\section{INDEX TERMS}

\section{Medical Subject Headings (MeSH)}

${ }^{\star}$ Air Ionization; Anions [therapeutic use]; Asthma [^therapy]; Cations [therapeutic use]; Cross-Over Studies; Ions [therapeutic use]; Randomized Controlled Trials as Topic

\section{MeSH check words}

Adolescent; Adult; Child; Child, Preschool; Humans; Infant; Young Adult 